\title{
Ny læreplan - for åpen i mange retninger
}

\section{Lareplan i kristendom, religion, livssyn og etikk (KRLE)}

Av KARI REPSTAD, tidligere universitetslektor i religionsdidaktikk ved Universitetet i Agder, mangeårig laerer $i$ videregående skole. Tidligere leder av Religionslarerforeningen i Norge.

I denne korte kommentaren til ny læreplan vil jeg prøve å se planen fra en lærersynsvinkel. Da ser jeg at planen har god tilknytning til ny Overordnet del av læreplanverket og at føringene om objektiv, kritisk og pluralistisk undervisning i faget er bra. Faget blir, slik det er beskrevet i Om faget-delen, veldig bredt og omfattende. Men med god undervisning vil det også gi elevene god oversikt.

Jeg har likevel noen innvendinger mot planen slik den er utformet. Den setter læreren i mange faglige valgsituasjoner fordi kompetansemålene ikke gir konkrete føringer for hva som det skal undervises i. For eksempel, når planen etter 10. trinn sier: «Elevene skal utforske sentrale trekk ved kristendommen og andre religionsog livssynstradisjoner og deres utbredelse i dag», ville jeg som lærer ønsket meg en presisering av hvilke religions- og livssynstradisjoner som er aktuelle å ta med. Jeg ville også spurt: Gjelder det for hele verden eller bare for Norge, eller bare for vårt lokalsamfunn?

Mange lærere legger opp undervisningen sin ut fra lærebøkene som skolen har valgt. Når læreplanen er upresis og litt «utflytende», blir det ofte til at lærebøkene styrer skolens innhold. Jeg tror at denne læreplanen er en slik plan der mange lærere vil støtte seg på lærebøkene fordi kompetansemålene er for brede og upresise. Hvilke historiske endringsprosesser skal en for eksempel ta med når kompetansemålet lyder: «Eleven skal kunne utforske og drøfte hvordan kristendom og andre religioner inngår i historiske endringsprosesser nasjonalt og globalt» (etter 10. trinn)?

Alle de ulike valgene som lærere gjør i sin undervisning, sammen med valg av lærebøker, kan lett føre til at elevene kommer ut av grunnskolen med ulik kunnskap. Karuss skole kan ha ett KRLE-fag, mens Oddemarka kan sende elevene ut med et annet. Et felles fag i skolen krever tydelig og presis læreplan.

Nå vil noen si at det er bra med stor valgfrihet i et fag i skolen, for lærerne er selvstendige fagpersoner som kan legge opp sin undervisning. Men, ikke alle lærere i grunnskolen har religion og livssyn som et spesielt fag i utdannelsen sin, de trenger derfor en læreplan som gjør det enkelt å legge opp undervisningen.

Læreplanen i KRLE legger til rette for at kristendom, jødedom, islam, buddhisme, hinduisme, sikhisme, nyreligiøsitet og livssynshumanisme kan behandles både enkeltvis og i sammenheng. Til sammen skal elevene bli godt 
kjent med bredden av religiøse og ikke-religiøse livssyn. Om lag halvparten av undervisningstiden i faget skal brukes på kristendomskunnskap. Her sies det ikke noe om hvilke religioner/ livssyn som skal prioriteres. Det blir det opp til læreren å velge.

Denne valgfriheten får også konsekvenser ut over grunnskolen. De elevene som vi møter i videregående skole, stiller med ulik kunnskap om religioner og livssyn, noe som er betydningsfullt for dem som skal gi undervisninga i VG3. Selv om dette ikke direkte berører fagfornyelsen, forblir det etter min mening et problem at elever ved yrkesfaglige studieprogrammer ikke har Religion og etikk i videregående skole og at de derfor vil risikere å være kunnskapsløse om viktige religiøse og livssynsmessige problemstillinger. Mange av disse elevene skal ut i jobber som krever kunnskap om andre menneskers religion og livssyn fordi de skal behandle dem som kunder eller pasienter.

Verbene «samtale», «utforske», «undersøke», «presentere», «drøfte», «reflektere» og «sammenlikne», går igjen på alle trinn i læreplanen, og verbene er alltid viktige for en lærers analyse av læreplanen. De sier noe om arbeidsmåter og om hva elevene skal kunne etter opplæringa. Verbene i denne planen ligger taksonomisk høyt, for høyt for mange av elevene, vil nok mange lærere si. Arbeidsmåtene som er aktuelle for å nå målene, er tidkrevende, og elevene må ha gode grunnkunnskaper for både å kunne sammenlikne og utforske. Sammenlikning er ofte vanskelig til og med i tredje klasse i videregående skole.

Og når nå verbet «sammenlikne» for eksempel brukes på alle trinn, tenker jeg at det kunne vært fint om læreplanen hadde antydet noen modeller som kunne brukes i arbeidet. Ninian Smarts enkle analysemodell ble brukt i forrige revisjon av Religion- og etikkfaget og har vist seg å være svært nyttig både for elever og lærere. Slik hjelp til lærere hadde vært fullt mulig å skrive inn i læreplanen.

Læreplan for KRLE-faget ligger tett opp til Ny overordnet del av læreplanverket og de verdiene som ligger der, og det er bra, samtidig ville jeg ønsket meg en læreplan som ligger nærmere klasserommet med 28 elever på ulike nivåer. 